ISSN: 2788-9688 Volume 1, Issue 2, pp 77-90, April 2021

Received: 23/5/2021 Revised: 31/5/2021 Accepted: 1/6/2021

\title{
Examining the Aspects Decrease the Development of the Small and Medium Enterprises in Al Batinah Province - Oman
}

\author{
Khaloud M. Al-Farsi ${ }^{1, *}$, Nebras Alattar ${ }^{1}$ \\ Faculty of Computing and Information Technology, Sohar University, Oman. \\ ${ }^{*}$ Corresponding author: Khaloud M. Al-Farsi,KFARSI@su.edu.om
}

\begin{abstract}
Small and medium-sized enterprises (SMEs) play an important role in any developing economy. In Oman, about $60 \%$ of SMEs are the source of employment. There is an increase in SMEs, but there are also challenges linked with growth; this research project explores the specific challenges faced by small and medium business owners. This study used a simple random sample with data from 200 SME owners, and data was collected using a well-design questionnaire. The data was analyzed in more detail by descriptive statistics and ANOVA statistics. A reliability test was performed to determine how reliable the data collecting instrument was. The limitations of this work and several suggestions are recorded. Several hypotheses are tested, and the results show a significant relationship between Financial management constraints and SME growth. And, also, there is a significant relationship between Marketing management constraints and the growth of SMEs. And, also, there is no significant relationship between the relationship of statistical importance between the Human resource constraints and the growth of SMEs in Oman.
\end{abstract}

Keywords: small and medium-sized enterprises; descriptive statistics; ANOVA statistics; marketing management provided the original work with proper citation. This work is licensed under Creative Commons Attribution International License (CC BY 4.0). 


\section{Introduction}

The small and medium local business sector is the most effective and sustainable solution to create more inclusive growth, involving most of companies and the largest employer in the world. Unlike foreign investment, which may be concentrated in a particular sector or region, local small and medium enterprises (SME) create opportunities in geographical regions and sectors and employ more labor-intensive and more diversified labor sectors (Collier, 2014). The SME sector is considered the backbone of the economy in high-income countries, while it is less developed in low-income countries (Govori, 2013). The SME sector is affected negatively during the COVID 19 pandemic (Zia et al., 2021). Researchers have explained that SMEs is usually based on four functional areas; human resource management, finance management, marketing management, and operations management (Levy B., 1993). It's a general fact that SMEs should focus on all these four areas if they want to gain success. It is important to study whether these factors have significant impacts on the growth of the SMEs in Oman, particularly in Al Bathinah province.

There was a fall in the number of SMEs in Oman in the first quarter of 2017, compared with the same period of 2016. Oman registered only 2,759 SMEs between January and March 2017, down from 4,013 as of March-end 2016 (National Centre for Statistics and Information , 2017). According to the data released by Small and Medium Enterprises Development (Riyada) regarding the number of SMEs in 2018 compared with 2017 in some Omani Provinces, it decreased of the number of SMEs. At the end of December 2018, the Province of Al Wusta registered a decline in the number of SMEs by 55.4 per cent compared with 2017, followed by the Province of South Al Batinah, which registered a fall of 47 percent. The Province of Al Dakhliyah registered a fall of 45.6 percent. (Times of Oman, February 4, 2019). Figure 1 shows Numbers of SMEs registered in 2017 \& 2018 in Oman.

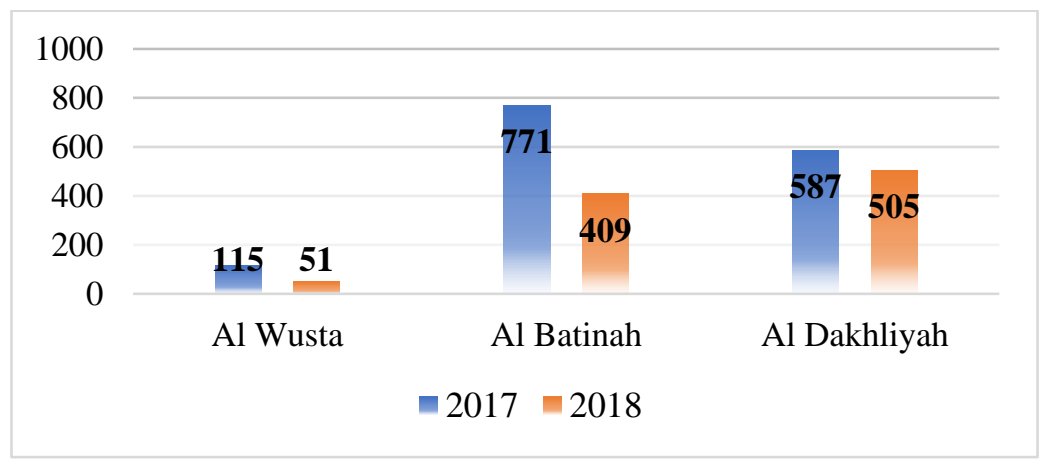

Figure 1. Numbers of SMEs registered in 2017 \& 2018 in Oman (Times of Oman, February 4, 2019). 
According to Riyadh Institute the activities in AL Bathinah province are divided into three main categories, namely activities that related to service, production and construction. The construction activities are almost $60 \%$ of overall activities across the region as shown Figure 2.

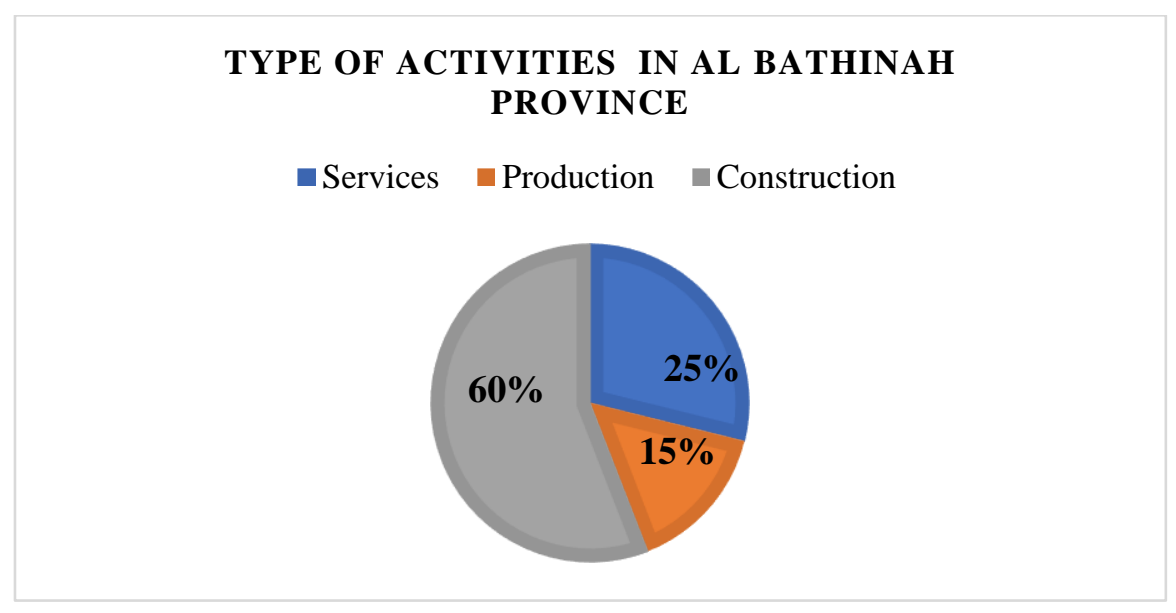

Figure 2. Type of activities in al Bathinah Province.

Source: Small and Medium Enterprises Development (Riyada)

In order to support and promote SMEs, the Omani government has provided many training and guidance to manage and train them so that they grow and succeed in the economy in a required manner (Buckley, 1989). The Omani government in recent years has made a significant contribution to the development and growth of SMEs, but in the first quarter of 2017 there has been a decline in the number of SMEs in Oman, compared with the same period in 2016. Between January and March 2017, it was recorded that there were 2,759 SME, compared to 4,013 in March 2016 (National Centre for Statistics and Information , 2017). For this reason, it is important to study the factors contributing to the decrease of the number of SME in Oman, particularly in Batinah Province. The factors that have direct implications to the operation of SME in other countries are considered in this research; which are human resource management, finance management, marketing management, and operations management. However, it is also important to identify other factors (if there is any) other than the above. This is because problems facing by SME is also related to the domestic or internal issues facing by that particular country. 


\section{Literature Review}

Studies have been conducted that SMEs have a significant impact and effect on the economy and society, but SMEs need a high level of strategic management of their operations so that these companies would run successfully (Yew Wong, 2005).

Many researchers have identified SME however, defining it is completely debatable. There are several criteria for identifying SMEs, including total investment, the number of workers in business, annual sales volume, market share in industry (Fink, 1998). All companies around the world identify SMEs based on a series of employees to manage their business. Definition of SMEs by number of employees and annual turnover in Oman are summarized in Table 1.

Table 1. Definition of SMEs by number of employees and annual turnover in Oman

\begin{tabular}{lll}
\hline Oman Tender Board & No. of employees & Annual Turnover \\
\hline Small & Up to 15 & 100,000 RO \\
Medium size (Grade 1) & Up to 250 & $1,000,000$ OR \\
Medium size (Grade 2) & Up to 100 & 500,000 OR \\
Medium enterprises (Grade Excellent) & over 250 employees & $1,000,000$ OR \\
Ministry of Commerce \& Industry & No. of employees & Annual Turnover \\
Micro Enterprises & $0-5$ & $<25,000$ OR \\
Small Enterprises & $6-20$ & $<25,000-2,50,00$ OR \\
Medium Enterprises & $21-100$ & $<2,50,000-1.5$ million OR \\
\hline
\end{tabular}

Source: Ministry of Commerce and Industry, 2011

\section{Research Methodology}

Research design is a schema and outline that performs the necessary actions and procedures to collect the information and data needed for the research structure and to solve the research problem. In this research, quantitative research is deployed to collect data through questionnaire and then convert them into digital forms using different statistical analyzes methods (Dörnyei, 2007). The qualitative research will test open responses to respondents with regard to the problems and challenges faced by SMEs in expanding business (Saini et al, 2011). The open answers will explain all situations that create an obstacle to the growth of SMEs, and in simple words, it will illustrate the results of quantitative data. On the other hand, descriptive research method is used to collect data to answer or solve 
all questions related to the research (Yousif et al., 2021). Statistical Package for the Social Sciences (SPSS) is used in this research to read and analyze the (quantitative data) that collected from the questionnaire.

\section{Martials and Methods}

\subsection{Research Instrument}

Questionnaires were used to collect quantitative research data. The main reason for choosing a questionnaire is to collect a large amount of research data from a large number of responders at low cost in a short time and efficiently. The questionnaires elements, including words, names, and questions, were simple, clear, easy and unambiguous, making it easier for respondents to understand questions to provide the correct answers.

In addition, the questionnaire elements were taken from previous questionnaires used by the other researcher the questionnaires were based on closed questions, but focused on selected variables from this research so that the research questions could be answered correctly. The questionnaire also focused on the biological data of the SMEs that responded and includes the following questions, age of the firm, ownership form, employees' number in the firm and average monthly turnover over the firm.

\subsection{Population and Sampling}

In this research, probability sampling is used because of a sampling frame available when this research uses probabilistic sampling, researchers may choose to collect data from the total population where each element has equal selection opportunities as part of the sampling process. Research population is a large collection of individuals or objects that are considered as main focus of the study (Ritchie, Lewis, Nicholls, \& Ormston, 2013). The population of this study is based on registered SME operating within the Sultanate of Oman. Sampling is an act, process or technique to select the best representative part of the population to fully characterize the population (Cochran, 2007). The Random sampling method to choose the sample from the population of this study. The sample size consists of 200 SMEs companies from the AL Batinah region. The reason for choosing the sample size is to make the data collected and the errors less searchable so that the search is true and reliable.

\subsection{Data Collection Method}

There are two ways of collecting data. In this research the two ways were used, primary data and secondary data. The two ways could provide information to answer the research question and research hypotheses through different 
methods. However, the two ways (primary and secondary) of collecting data are the data collection methods used in this research to explain the clear understanding. In this research, a survey questionnaire was conducted to collect primary data because it is simple and reliable for respondents. The questionnaire will be distributed at the respondents' business offices. In addition, the secondary data sources were obtained from journal articles and books to collect more information about the research project (Sapsford, Jupp, Sage. Teddlie, \& Yu, 2006-2007).

\subsection{Research Questions and Hypotheses}

The research questions are:

- What are the challenges and causes that limited the growth of SME in AL Batinah province?

- What are the possible recommended strategies to avoid or reduce failure of SME in Oman?

Following are the research hypotheses of this study:

H1: Financial management constraints have a negative effect and impact on the growth of SME.

H2: Marketing management constraints have a negative effect and impact on the growth of SME.

H3: Human resource management constraints have a negative effect on growth of SME.

H4: Government constraints have a negative effect and impact on the growth of SME.

\section{Results and Discussion}

This section presents the result of the data which had been collected from 200 respondents, the business owner of SME from AL Batinah province. Also, it summarizes the findings and contributions made data and variables were analyzed in which the results of the questionnaire were entered using the statistical package of the Social Sciences Program (SPSS). This was done to analyze the collected data and ensure the accuracy of the results and the descriptive analysis was carried out.

\subsection{The Results of Descriptive Analysis}

The results begin with the analysis and reports on general information with respect to the respondents. The second part follows with reports regarding the extent to which financial management, marketing management, human resource management and government policies has influenced the growth of SME. 
Table 2. The results of descriptive analysis

\begin{tabular}{|c|c|c|c|c|c|}
\hline & & Frequency & Percent & Valid Percent & $\begin{array}{c}\text { Cumulative } \\
\text { Percent }\end{array}$ \\
\hline \multirow{7}{*}{$\begin{array}{l}\text { Age of the } \\
\text { Owner } \\
\text { Valid\# }\end{array}$} & Below 21 & 47 & 23.5 & 23.5 & 23.5 \\
\hline & 21-30 years & 74 & 37.0 & 37.0 & 60.5 \\
\hline & 31-40 year & 55 & 27.5 & 27.5 & 88.0 \\
\hline & $14-50$ years & 14 & 7.0 & 7.0 & 95.0 \\
\hline & 51-60 years & 9 & 4.5 & 4.5 & 99.5 \\
\hline & Above 60 years & 1 & 0.5 & 0.5 & 100.0 \\
\hline & Total & 200 & 100.0 & 100.0 & \\
\hline \multirow{4}{*}{$\begin{array}{l}\text { Gender of the } \\
\text { Owner } \\
\text { Valid\# }\end{array}$} & Male & 130 & 65.0 & 65.0 & 65.0 \\
\hline & Female & 68 & 34.0 & 34.0 & 99.0 \\
\hline & N/A & 2 & 1.0 & 1.0 & 100.0 \\
\hline & Total & 200 & 100.0 & 100.0 & \\
\hline \multirow{7}{*}{$\begin{array}{l}\text { Qualification } \\
\text { of the Owner } \\
\text { Valid\# }\end{array}$} & High school & 45 & 22.5 & 22.5 & 22.5 \\
\hline & Diploma & 71 & 35.5 & 35.5 & 58.0 \\
\hline & Bachelor & 59 & 29.5 & 29.5 & 87.5 \\
\hline & Masters & 23 & 11.5 & 11.5 & 99.0 \\
\hline & PHD & 1 & 0.5 & 0.5 & 99.5 \\
\hline & $\begin{array}{l}\text { Others } \\
\text { (workshop / } \\
\text { training) }\end{array}$ & 1 & 0.5 & 0.5 & 100.0 \\
\hline & Total & 200 & 100.0 & 100.0 & \\
\hline \multirow{6}{*}{$\begin{array}{l}\text { Work } \\
\text { Experience } \\
\text { Valid\# }\end{array}$} & $\begin{array}{l}5 \text { years and } \\
\text { below }\end{array}$ & 109 & 54.5 & 54.5 & 54.5 \\
\hline & 6-10 years & 40 & 20.0 & 20.0 & 74.5 \\
\hline & 11-15 years & 37 & 18.5 & 18.5 & 93.0 \\
\hline & 16-20 years & 10 & 5.0 & 5.0 & 98.0 \\
\hline & $\begin{array}{l}\text { More than } 20 \\
\text { years }\end{array}$ & 4 & 2.0 & 2.0 & 100.0 \\
\hline & Total & 200 & 100.0 & 100.0 & \\
\hline \multirow{5}{*}{$\begin{array}{l}\text { Type of } \\
\text { Business } \\
\text { Valid\# }\end{array}$} & Production & 34 & 17.0 & 17.0 & 17.0 \\
\hline & Service & 89 & 44.5 & 44.5 & 61.5 \\
\hline & Construction & 36 & 18.0 & 18.0 & 79.5 \\
\hline & Other & 41 & 20.5 & 20.5 & 100.0 \\
\hline & Total & 200 & 100.0 & 100.0 & \\
\hline \multirow{3}{*}{$\begin{array}{l}\text { Do you have } \\
\text { Business } \\
\text { plan? } \\
\text { Valid\# }\end{array}$} & Yes & 135 & 67.5 & 67.5 & 67.5 \\
\hline & No & 65 & 32.5 & 32.5 & 98.0 \\
\hline & Total & 200 & 100.0 & 100.0 & \\
\hline
\end{tabular}




\begin{tabular}{|c|c|c|c|c|c|}
\hline \multirow{7}{*}{$\begin{array}{l}\text { Average } \\
\text { monthly net } \\
\text { income of the } \\
\text { business } \\
\text { Valid\# }\end{array}$} & $\begin{array}{l}\text { Less than500 } \\
\text { RO }\end{array}$ & 59 & 29.5 & 29.5 & 29.5 \\
\hline & 500-1000 RO & 58 & 29.0 & 29.0 & 58.5 \\
\hline & $1000-2000$ RO & 42 & 21.0 & 21.0 & 79.5 \\
\hline & 2000-3000RO & 18 & 9.0 & 9.0 & 88.5 \\
\hline & 3000-4000RO & 10 & 5.0 & 5.0 & 93.5 \\
\hline & $\begin{array}{l}\text { More than } \\
4000 \text { RO }\end{array}$ & 13 & 6.5 & 6.5 & 100.0 \\
\hline & Total & 200 & 100.0 & 100.0 & \\
\hline
\end{tabular}

From the above Table 1, it is observed that $37 \%$ of the respondents are from 21 to 30 years old, which is the highest, followed by $27.5 \%$ from $31-40$ year, while the above 60 years old got the lowest number of respondents, which is $0.5 \%$. A total 200 respondents were asked to fill the questionnaire and all of them belonged to different age groups. It is really good for this research that respondents are of different age because, in this way, their business experience varies and can better highlight the challenges and issues that they face in growing or expanding their SME. It is observed that $34 \%$ of the respondents were female while $65 \%$ of them were male. The majority of the participants were men because more men were able to manage SMEs in Oman. The main reason for this is the male society that dominates Oman and it is useful to look for data for men who run SMEs in Oman. The research respondents possess different educational background. For example, $35.5 \%$ of the respondents have diploma, while $29.5 \%$ of them have bachelor degree, $22.5 \%$ have high school certificate and 5\% lowest number have PHD. It is really important for the research because, with a different educational background, SME faces different type of challenges and issues in growing their business. It is observed that $54.5 \%$ have 5years and below works experience, while $20 \%$ have experience between 6 to 10 years and above 20 years work experience got the lowest number of respondents, which is $2 \%$.

The type of business in AL Bathinah province. 44.5\% from the respondents have activities that related to service, while $18 \%$ those who have activities that related to construction and $17 \%$ for production activities. A total of $67.5 \%$ from the respondents have a business plan while on the other hand 32.5 do not have any. The respondents have monthly net income less than $500 \mathrm{RO}$ and $29 \%$ their monthly net income between 500-1000 RO. 21\% have net income between 1000-2000 RO, while 9\% their net income between 2000-3000 RO. 6.5\% from the respondents have monthly net income more than $4000 \mathrm{RO}$. The analysis of the independent and dependent variables affects the growth of SMEs in terms of financial management, marketing management, human resource management, government policies is presented in Table 2. Table 2 shows that the mean and standard deviation of the independent and dependent variable. 
The variable that has highest mean value among the variables is the Finance management which is 2.6620 with the highest standard deviation of 0.82546 and the lowest mean value among the variables is the SME growth which is 1.9925 with the standard deviation of 0.51118 .

Table 3. Mean and standard deviation analysis of variable

\begin{tabular}{lccc}
\hline & DESCRIPTIVE STATISTICS & \\
& Mean & Std. Deviation & $\mathrm{N}$ \\
\hline SME growth & 1.9925 & 0.51118 & 200 \\
Finance management & 2.6620 & 0.82546 & 200 \\
Marketing management & 2.4775 & 0.56776 & 200 \\
HR management & 2.3380 & 0.40568 & 200 \\
Government policy & 2.2690 & 0.64772 & 200 \\
\hline
\end{tabular}

Table 2 shows that the mean and standard deviation of the independent and dependent variable. The variable that has highest mean value among the variables is the Finance management which is 2.6620 with the highest standard deviation 0.82546 and the lowest mean value among the variables is the SME growth which is 1.9925 with the standard deviation 0.51118 .

\subsection{Reliability Analysis}

The reliability test Cronbach's Alpha is the test of the reliability of all the variables, and the minimum 0.6 can be considered to be highly reliable in and 0.5 is weak reliable. Reliability analysis was conducted for four variables, financial management, marketing management, human resource management and government policies. As can be seen from the results Cronbach's Alpha the SME growth is 0.644 and is considered acceptable and good for reliability, also the results Cronbach's Alpha the financial management is 0.493 Which is weak but still acceptable. And Cronbach's Alpha the results for marketing management, human resource management and government policies which are weak but still acceptable. 


\subsection{Regression Analysis}

Linear regression analysis is used to predict independent and dependent variables of the research and uses ANOVA and parameter value and analysis of data used in the research. The value of the squares R shown in the summary table model also shows the convergence of variables. Regression analysis was conducted to test if there is a significant relationship between, financial management, marketing management, human resource management, government policies in the growth of SMEs Oman. Table 3 shows the summary of the model, the value of R Square is 0.594 of the percentage $59.4 \%$, which mean all independent variables can affect to the dependent variables by $59.4 \%$.

Table 4. The summary of the regression model

\begin{tabular}{|c|c|c|c|c|c|c|c|c|c|}
\hline \multirow[b]{3}{*}{ Model } & \multicolumn{9}{|c|}{ MODEL SUMMARY } \\
\hline & \multirow[b]{2}{*}{$\mathrm{R}$} & \multirow[b]{2}{*}{$\begin{array}{c}\mathrm{R} \\
\text { Square }\end{array}$} & \multirow[b]{2}{*}{$\begin{array}{l}\text { Adjusted } \\
\text { R Square }\end{array}$} & \multirow[b]{2}{*}{$\begin{array}{l}\text { Std. Error of } \\
\text { the Estimate }\end{array}$} & \multicolumn{5}{|c|}{ Change Statistics } \\
\hline & & & & & $\begin{array}{l}\text { R Square } \\
\text { Change }\end{array}$ & $\begin{array}{c}\text { F } \\
\text { Change }\end{array}$ & df1 & df2 & $\begin{array}{l}\text { Sig. F } \\
\text { Change }\end{array}$ \\
\hline 1 & $0.771^{\mathrm{a}}$ & 0.594 & 0.585 & 0.32915 & 0.594 & 71.239 & 4 & 195 & 0.000 \\
\hline \multicolumn{10}{|c|}{$\begin{array}{l}\text { a. Predictors: (Constant), government, HR management, finance management, marketing management. b. D } \\
\text { Variable: SME growth }\end{array}$} \\
\hline & \multicolumn{9}{|c|}{ Table 5. The summary of the ANOVA test } \\
\hline & \multicolumn{9}{|c|}{ ANOVA $^{\mathbf{a}}$} \\
\hline & \multicolumn{2}{|c|}{ Model } & \multicolumn{2}{|c|}{ Sum of Squares } & df & Iean Square & & $\mathbf{F}$ & Sig. \\
\hline & \multirow[t]{3}{*}{1} & Regression & \multicolumn{2}{|c|}{30.872} & 4 & 7.718 & & 71.239 & $0.000^{\mathrm{b}}$ \\
\hline & & Residual & \multicolumn{2}{|c|}{21.126} & 195 & 0.108 & & & \\
\hline & & Total & \multicolumn{2}{|c|}{51.999} & 199 & & & & \\
\hline
\end{tabular}

a. Dependent Variable: SME growth

Dependent and independent variables can be considered if $\mathrm{P}$ less than 0.05 . Table 4 shows that the value of $\mathrm{F}$ is 71.239 and the significantly value is 0.000 that means that $\mathrm{P}$ value less than 0.05 .

\subsection{Answer the Hypotheses}

This section discusses the result of the hypotheses and explains if they are supported or no.

H1: Financial management constraints have a negative effect and impact on the growth of SME. 
According to the table above, the independent beta coefficient of the variable of the expected is 0.306 , The important value of the average independent variable is 0.000 Which means that $\mathrm{P}$ less than 0.05 Therefore it is concluded that H1 with the existence of a relationship of statistical significance between the Financial management constraints and the growth of SME.

H2: Marketing management constraints have a negative effect and impact on the growth of SME. According to the table above, the independent beta coefficient of the variable of the expected is -0.224 The important value of the average independent variable is 0.000 Which means that $\mathrm{P}$ less than 0.05 Therefore it is concluded that $\mathrm{H} 2$ with the existence of a relationship of statistical significance between the Marketing management constraints and the growth of SME.

\section{H3: Human resource management constraints have a negative effect on growth of SME.}

According to the above table, the independent beta coefficient of the expected variable is -0.087 the important value of the mean independent variable is 0.118 which means that $\mathrm{P}$ is more than 0.05 . Therefore, we concluded that $\mathrm{H} 3$ with no relationship of statistical importance between the Human Resource constraints and the growth of SME in Oman.

\section{H4: government constraints have a negative effect and impact on the growth of SME.}

According to the table above, the independent beta coefficient of the variable of the expected is 0.648 The important value of the average independent variable is 0.000 Which means that $P$ less than 0.05 Therefore it is concluded that $\mathrm{H} 4$ with the existence of a relationship of statistical significance between the Government Constraints and the growth of SME. Table 5 present a summary of the hypotheses results.

Table 6. The summary of the hypotheses test

\begin{tabular}{lll}
\hline & \multicolumn{1}{c}{ Hypotheses } & Result \\
\hline H1 & $\begin{array}{l}\text { Financial management constraints have a negative effect and } \\
\text { impact on the growth of SME }\end{array}$ & Supported \\
H2 & $\begin{array}{l}\text { Marketing management constraints have a negative effect and } \\
\text { impact on the growth of SME }\end{array}$ & Supported \\
H3 & $\begin{array}{l}\text { Human resource management constraints have a negative } \\
\text { effect on growth of SME }\end{array}$ & Not supported \\
H4 & $\begin{array}{l}\text { Government constraints have a negative effect and impact on } \\
\text { the growth of SME }\end{array}$ & Supported \\
\hline
\end{tabular}




\section{Conclusion}

This work is deployed a quantitative research methodology. A total of 200 respondents were asked to fill the questionnaire, and all of them belonged to different age groups. It is perfect for this research that respondents are of varying ages because and business experience. It can better highlight the challenges and issues that they face in growing or expanding their SME. A total of $67.5 \%$ of the respondents have a business plan, while on the other hand, 32.5 do not have any plan. The analysis of the independent and dependent variables affects the growth of SMEs in terms of financial management, marketing management, human resource management, government policies. The variable with the highest mean value among the variables is Finance management which is 2.6620 with the highest standard deviation of 0.82546 . The lowest mean value among the variables is the SME growth which is 1.9925 with a standard deviation of 0.51118 . Also, it is observed that there is a significant and positive relationship between financial management, marketing management, human resource management, and government policies on the growth of SMEs.

This research successfully answered all research questions and accepted hypothesis but, research limitations are following:

- The study was cross-sectional due to lack of research time and was an important constraint on research.

- Survey respondents did not show any interest in answering questionnaires. An important limitation of this study was that respondents responded quickly and provided answers to questions. It was really hard because it was a waste of time for them

- Some of the respondents do not understand the English language, the translation of the questionnaires took a lot of time.

Future research should be conducted using the same independent and dependent variables, but small and mediumsized enterprises in developing countries should be compared to SMEs in developed countries. In this way, research will show that SMEs in developed countries are thriving and constantly move towards growth or expansion. In addition, this difference should highlight strategies used by SMEs in developed countries to overcome challenges and problems in developing their growth strategies. 


\section{References}

Al-Lamki, S. M. (2000). Omanization: A Three Tier Strategic Framework for Human Resource Management and Training in the Sultanate of Oman. Journal of Comparative International Management, 3(1).

Buckley, P. J. (1989). Foreign direct investment by small-and medium-sized enterprises: the theoretical background The Multinational Enterprise . Springer, 24-45.

Carbo-Valverde, S., Rodriguez-Fernandez, F., \& Udell, G. F. (2009). Bank market power and SME financing constraints. Review of Finance, 13(2), 309-340.

Carlson, D. S., Upton, N., \& Seaman, S. (2006). The Impact of Human Resource Practices and Compensation Design on Performance: An Analysis of Family-Owned SMEs. Journal of Small Business Management, 44(4), 531-543.

Carman, J. M., \& Langeard, E. (1980). Growth strategies for service firms. Strategic Management Journal, 1(1), 7-22.

Carson, D., \& Gilmore, A. (2000). SME marketing management competencies. International Business Review, 9(3), 363-382.

Cochran, W. G. (2007). Sampling Techniques. John Wiley \& Sons.

Collier, T. S. (2014, 5 11). Five steps that create inclusive growth through SMEs. Retrieved from The Broker: http://www.thebrokeronline.eu

del Brío, J., \& Junquera, B. (2003). A review of the literature on environmental innovation management in SMEs: implications for public policies. Technovation, 23(12), 939-948.

Dörnyei, Z. (2007). Research methods in applied linguistics: Quantitative, qualitative, and mixed methodologies. Oxford University Press.

Fink, D. (1998). Guidelines for the successful adoption of information technology in small and medium enterprises. International journal of information management, 18(4), 243- 253.

Fraenkel, J. R., Wallen, N. E., \& Hyun, H. H. (1993). How to design and evaluate research in education (Vol. 7). New York: McGraw-Hill.

Gelinas, R., \& Bigras, Y. (2004). The characteristics and features of SMEs: favorable or unfavorable to logistics integration? Journal of Small Business Management, 42(3), 263- 278.

Govori, A. (2013). Factors Affecting the Growth and Development of SMEs: Experiences from Kosovo. Mediterranean Journal of Social Sciences, 701-708.

Grossman, P. L., Smagorinsky, P., \& Valencia, S. (1999). Appropriating tools for teaching English: A theoretical framework for research on learning to teach. American Journal of Education, 1-29.

Gupta, A. K., \& Govindarajan, V. (1984). Business unit strategy, managerial characteristics, and business unit effectiveness at strategy implementation. Academy of Management journal, 27(1), 25-41.

Heneman, R. L., Tansky, J. W., \& Camp, S. M. (2000). Human resource management practices in small and medium-sized enterprises: Unanswered questions and future research perspectives. Entrepreneurship: Theory and Practice, 25(1), 1111.

Hyytinen, A., \& Toivanen, O. (2005). Do financial constraints hold back innovation and growth?: Evidence on the role of public policy. Research Policy, 34(9), 1385-1403.

Juan García-Teruel, P., \& Martinez-Solano, P. (2007). Effects of working capital management on SME profitability. International Journal of managerial finance, $3(2), 164-177$.

Zia, K., Farooq, U., \& Shafi, M. (2021). COVID-19 Outbreak: Model-Driven Impact Analysis Comparing Oman and Pakistan. Applied computing Journal, 38-54.

Knight, G. A. (2001). Entrepreneurship and strategy in the international SME. Journal of international management, 7(3), $155-171$.

Lamon, S. J. (2007). Rational numbers and proportional reasoning: Toward a theoretical framework for research. Second handbook of research on mathematics teaching and learning, 1, 629-667. 
Levy, B. (1993). Obstacles to developing indigenous small and medium enterprises: an empirical assessment. The World Bank Economic Review, 7(1), 65-83.

Levy, M., \& Powell, P. (2004). Strategies for Growth in SMEs: The Role of Information and Information Sytems. ButterworthHeinemann.

National Centre for Statistics and Information . (2017, 5 2). Dramatic Drop in Number of SMEs in Oman in 2017. Retrieved from Al Bawaba Business: https://www.albawaba.com/

Nguyen, T. V., \& Bryant, S. E. (2004). A study of the formality of human resource management practices in small and mediumsize enterprises in Vietnam. International small business journal, 22(6), 595-618.

Quayle, M. (2002). E-commerce: the challenge for UK SMEs in the twenty-first century. International Journal of Operations \& Production Management, 22(10), 1148-1161.

Quinn, J. B., Baruch, J. J., \& Zien, K. A. (1997). Innovation explosion: using intellect and software to revolutionize growth strategies. Simon \& Schuster.

Renuka, S. D., \& Venkateshwara, B. A. (2006). A comparative study of human resource management practices and advanced technology adoption of SMEs with and without ISO certification. Singapore Management Review, 28(1), 41.

Ritchie, J., Lewis, J., Nicholls, C., \& Ormston, R. (2013). Qualitative research practice: A guide for social science students and researchers. Sage.

Rodrik, D., Saleh, A. S., \& Ndubisi, N. O. (2005). SME development in Malaysia: Domestic and global challenges. Growth strategies. Handbook of economic growth, 1, 967-1014.

Saini, S. L., Saini, D. K., Yousif, J. H., \& Khandage, S. V. (2011, July). Cloud computing and enterprise resource planning systems. In Proceedings of the world Congress on Engineering (Vol. 1, pp. 681-684).

Sandgren, C. D. (1988). Growth and reproductive strategies of freshwater phytoplankton. Cambridge University Press.

Sapsford, R., Jupp, V., Sage. Teddlie, C., \& Yu, F. (2006-2007). (2006) Data collection and analysis: Sage. Teddlie, Charles, \& Yu, Fen. (2007). Mixed methods sampling a typology with examples. Journal of mixed methods research, 1(1), 77-100.

Smeral, E. (1998). The impact of globalization on small and medium enterprises: new challenges for tourism policies in European countries. Tourism Management, 19(4), 371-380.

Van de Vrande, V., De Jong, J. P., Vanhaverbeke, W., \& De Rochemont, M. (2009). Open innovation in SMEs: Trends, motives and management challenges. Technovation, 29(6), 423-437.

Wierenga, B., Van, B., \& Gerrit, H. (1998). The dependent variable in research into the effects of creativity support systems: Quality and quantity of ideas. MIS Quarterly, 81-87.

Yew Wong, K. (2005). Critical success factors for implementing knowledge management in small and medium enterprises. Industrial Management \& Data Systems, 105(3), 261-279.

Yousif, J. H., Khan, F. R., Zia, K., \& Saadi, N. A. (2021). Analytical Data Review to Determine the Factors Impacting Risk of Diabetes in North Al-Batinah Region, Oman. International Journal of Environmental Research and Public Health, 18(10), 5323. 